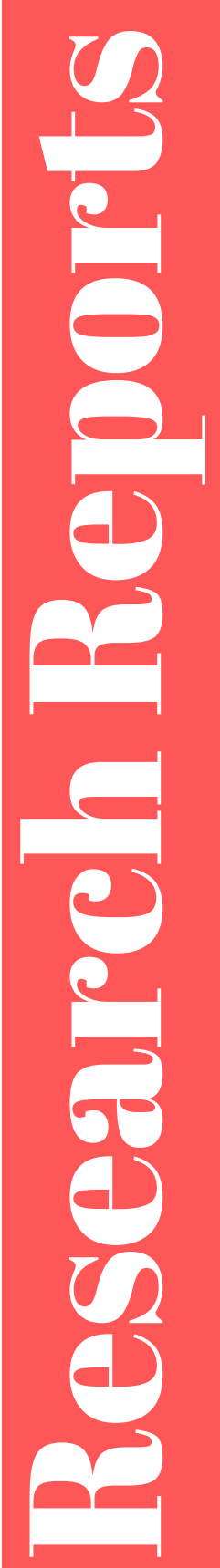




\title{
Research on English Teaching Policies for Public Schools: \\ From Past to Future Paths
}

\author{
Estudio de las pólizas para la enseñanza de inglés en las escuelas \\ publicas: De el pasado a futuros caminos
}

\section{Mireya Esther Castañeda Usaquen}

Secretaría de Educación del Distrito-SED

mecastaneda@educacionbogota.edu.co

Received: December 3, 2019

Accepted: December 24, 2019

How to cite this article (APA, 6th ed.):

Castañeda, M. E. (2019). Research on English teaching policies for public schools: From past to future paths. ENLETAWA Journal, 12(2), 11-41.

\begin{abstract}
The following paper introduces research studies and publications that could broaden English language teachers and scholars' understanding about policies for the teaching of English, targeted at public primary schools in various countries of the world. This article also explains how these policies have been addressed in these institutions depending on their needs, the contexts, and the perspectives of teachers, administrators, and stakeholders.
\end{abstract}

Key words: teaching English to children, policies for the teaching of English, public primary schools.

\section{Resumen}

El siguiente documento presenta una revisión de estudios de investigación y publicaciones que podrían ampliar la comprensión acerca de las políticas para la enseñanza del inglés, dirigidas hacia las escuelas primarias públicas en varios países del mundo. Este artículo también explica cómo se han abordado las políticas educativas de la enseñanza y aprendizaje de inglés en diferentes instituciones en función de sus necesidades, contextos y perspectivas de los maestros, administradores y partes interesadas.

Palabras claves: educación publica primaria, enseñanza de inglés a niños, politícas de la enseñanza de inglés 


\section{Introduction}

English language teaching has spread around the world and, in this article, I aim at profiling studies dealing with English as a Foreign Language (EFL henceforth) policies in the public school system with a focus on elementary school. In order to show the panorama of studies and reflection in EFL policies, I decided to take you through the journey of my how I began selecting the article to profile up until the point when I acknowledge what scholars want to explore or might not have noticed yet about English language teaching in public settings. This article is a story that I have organized in the following sections:

1. A Journey Traced my Own Path: The route I took to find the information I was looking for.

2. Source of Curiosity: The journals where I found the articles and geographical locations where the studies and/or reflections took place, as well as a timeline.
3. Treasure During the Journey: The tendencies I perceived related to the research interest and issues in EFL policies explained in the following four subsections:

a. Down to Earth

b. Inequality in the Access to Educational Resources

c. Public Education Quality

d. Challenges When Implementing $\quad E F L$ Policies

4. Researchers'Voices: I took into account the researcher's voices, as well as their proposals in relation to teacher programs and EFL policy implementation, which I organized in three main cores:

a. Voices for Policymaking 


\section{b. Teachers' Programs \\ c. Hopeful Perspectives}

5. Some Gaps in Relation to Teachers' Practices: I consider the future for EFL policy research in public schools, such as what researchers would like to explore next and what may be missing in the literature.

My goal with this article is to shed light on the past, present, and future of EFL policy research, as well as share my journey and experiences as a researcher and EducationELT doctoral student at the Universidad Francisco José de Caldas, Colombia.

\section{A Journey Traced my Own Path}

Without a doubt, the information on EFL teaching policies in public schools is both substantial and intricate. I began this process by making decisions on the core areas I wanted to explore. Consequently, I started to find information with key words like bilingual-elementary-education.
Studies and information on "bilingual" schools appeared frequently. Based on the preexisting data, I decided to focus on the key words early-public-English-LanguageTeaching-ELT. However, most of the articles were associated with the way teacher and students developed their language skills, methodologies, proficiency tests, etc. Professor Pilar Méndez asked me questions that allowed me to reflect on my own interests and context. Based on her advice, I opted for early-public-EFLschooling. As one might expect, searching for these words yielded an abundance of articles. Likewise, I considered looking for these words in Spanish: Enseñanza del inglés para niños en colegios públicos [Teaching English to children in public schools]. I selected the phrase: EFL policies in public schools to continue reviewing research articles. In order to illustrate this process, I designed Figure 1, which is a timeline that shows the research phrases I searched for in order. 


Bilingual
elementary
education

Figure 1. Timeline displaying research phrases transformation

Bearing in mind the above, I took

advantage of the Bdigital databases available at the university, which provided access to a wide variety of sources and database like Scopus. I found five articles in Scopus, five papers in Researchgate, and three papers in Scielo. Nevertheless, I found it difficult to access these files due to restrictions and fees. After struggling with these databases,
EFL policies in public schools

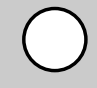




\section{Source of Curiosity}

The figure below (Figure 2) displays articles reviewed in relation to English language teaching in public schools.

the names of the journals and number of

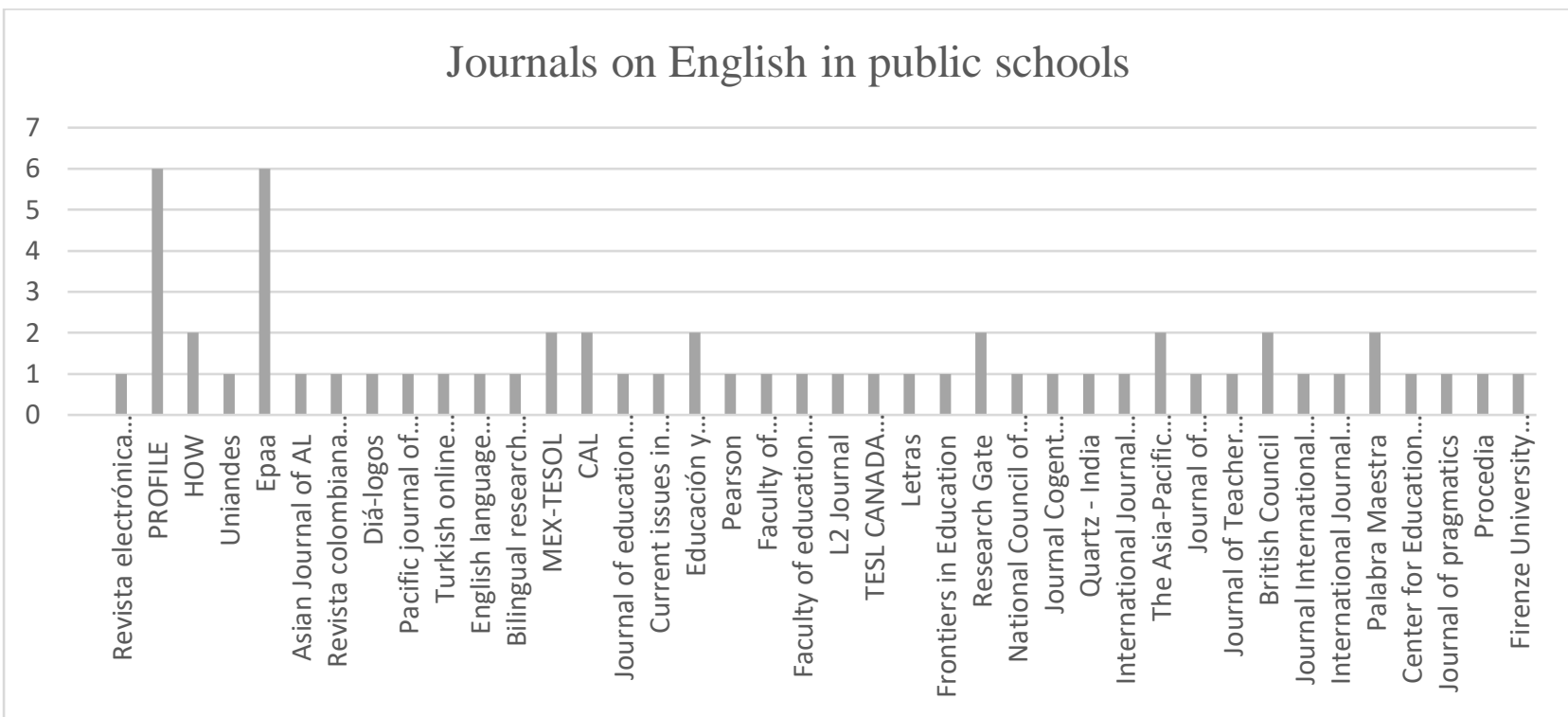

Figure 2. Journals with articles on EFL in Public Schools

As one can notice from the figure, only two journals published six articles related to the topic. They are PROFILE from Colombia and EPAA from Mexico. The former contains issues on teachers' professional development with many articles written by in-service teachers, who work in public institutions primarily. The latter published a special issue in 2016 titled English Language Teaching in Public Primary Schools in Latin America, which was compiled by José Luis Ramírez Romero and Peter Sayer. The rest of the journals contained one or two articles related to the topic of interest.

As I wanted to have a wide background to acknowledge the research problem from diverse perspectives and geographical locations, I designed Figure 3 below. The figure displays the places where scholars did their research studies and the number of articles per country. 


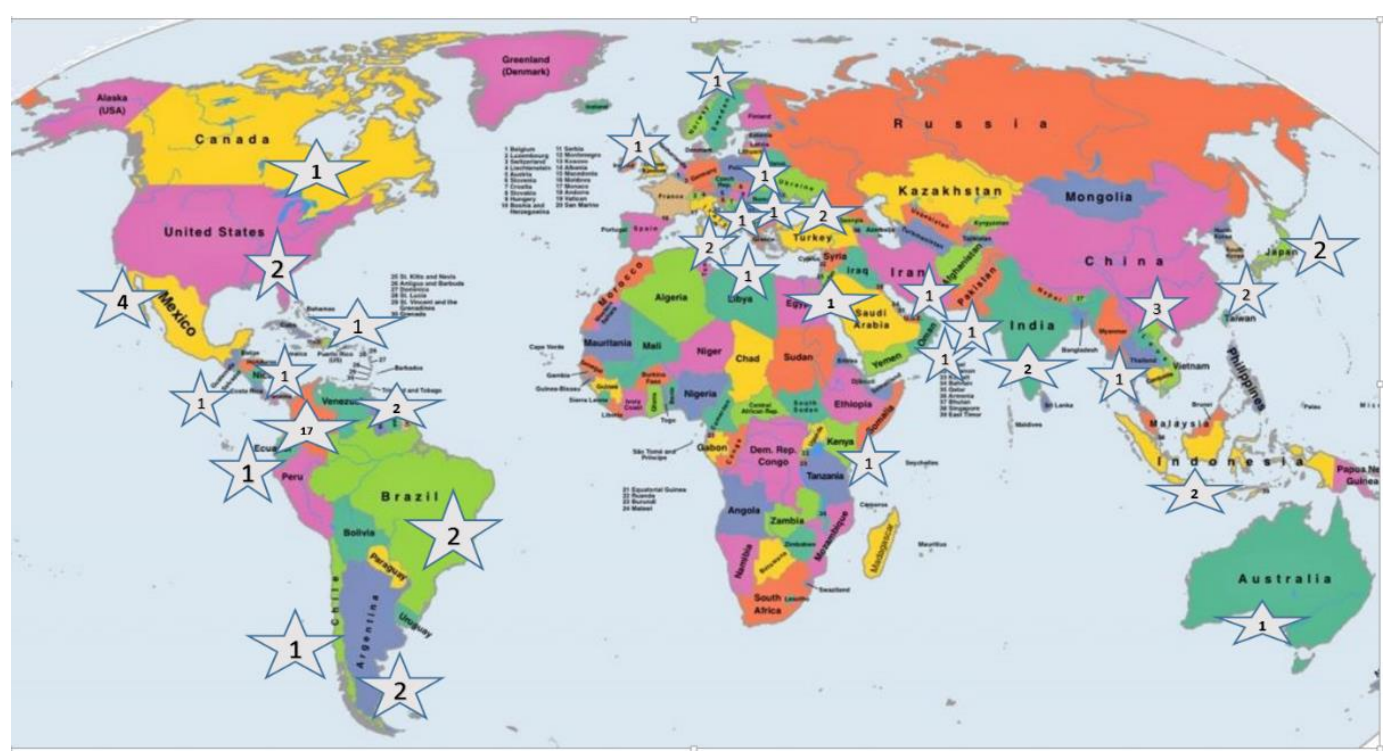

Figure 3. Researchers' origin and number of articles

As seen in Figure 3, the majority of the articles written about EFL policies and public primary education were authored by Colombian researchers. In total, I found 17 articles written by Colombian authors, of which one was published in a Canadian journal and another two in Mexican journals. The next most prolific country is Mexico, with four articles published by Mexican scholars. The remaining published authors come from 26 other countries. It caught my attention that Carol Benson
(2004), a Swedish researcher, looked into the teaching of English in Bolivia and Mozambique, both of which are multicultural nations. For the most part, Bolivia is rarely mentioned in Latin American EFL studies, and Mozambique (see Figure 3) does not have any published authors who have researched these topics.

To complete the picture, I considered it relevant to display the years the articles were published since 2000 on a timeline (see Figure 4).

\begin{tabular}{llllllllllll} 
Year & $2000-$ & 2009 & 2010 & 2011 & 2012 & 2013 & 2014 & 2015 & 2016 & 2017 & 2018 \\
\hdashline & $\begin{array}{l}2009 \\
6\end{array}$ & 5 & 3 & 2 & 6 & 4 & 2 & 6 & 13 & 9 & 2
\end{tabular}

Figure 4. Year of publication and total of publications 
In Figure 4, the year 2016 was fruitful in terms of publications. There were 13 articles, for which the special issue in EPAA contributed six of them. One of the reasons why the number of articles related to ELT in primary schools have picked up recently could be because it is a recent concept in EFL research. Hayes and Almeida coincide with this idea, with the former explaining this phenomenon in Asia, while the latter provides examples from Brazil and the Rio Global Child Project of 2016.

Having considered the origins of the articles in geographical terms and the number of publications between 2000 and 2018, it was time to look into the findings, problems tackled, and/or recommendations provided by other scholars.

\section{Treasure during the Journey}

Now, I show the way in which I organized the articles keeping the findings in mind, as Professor Harold Castañeda suggested. First, I summarized the problem that each study tackled. I grouped the articles into four main sections, as shown in Figure 5. I titled the first section Down to Earth, which contains articles related to problems faced by students on a daily basis and the risk of losing students' diversity in the homogenizing process. The second section, Inequality in the Access to Educational Resources, contains the dilemma between public and language schools when it comes to EFL teaching and learning. Additionally, the articles explained how textbooks are almost always the only resource used to teach English in primary schools. The third section explores the Quality of Public Education in relation to governmental perspectives and intentions with EFL policies in public schools. Finally, the fourth section speaks about the Challenges when Implementing EFL Policies in public schools, especially in the primary school sector. Furthermore, the articles in this section take into account teachers' qualifications and administrative 
issues. The figure below summarizes the

topics discussed in each section.

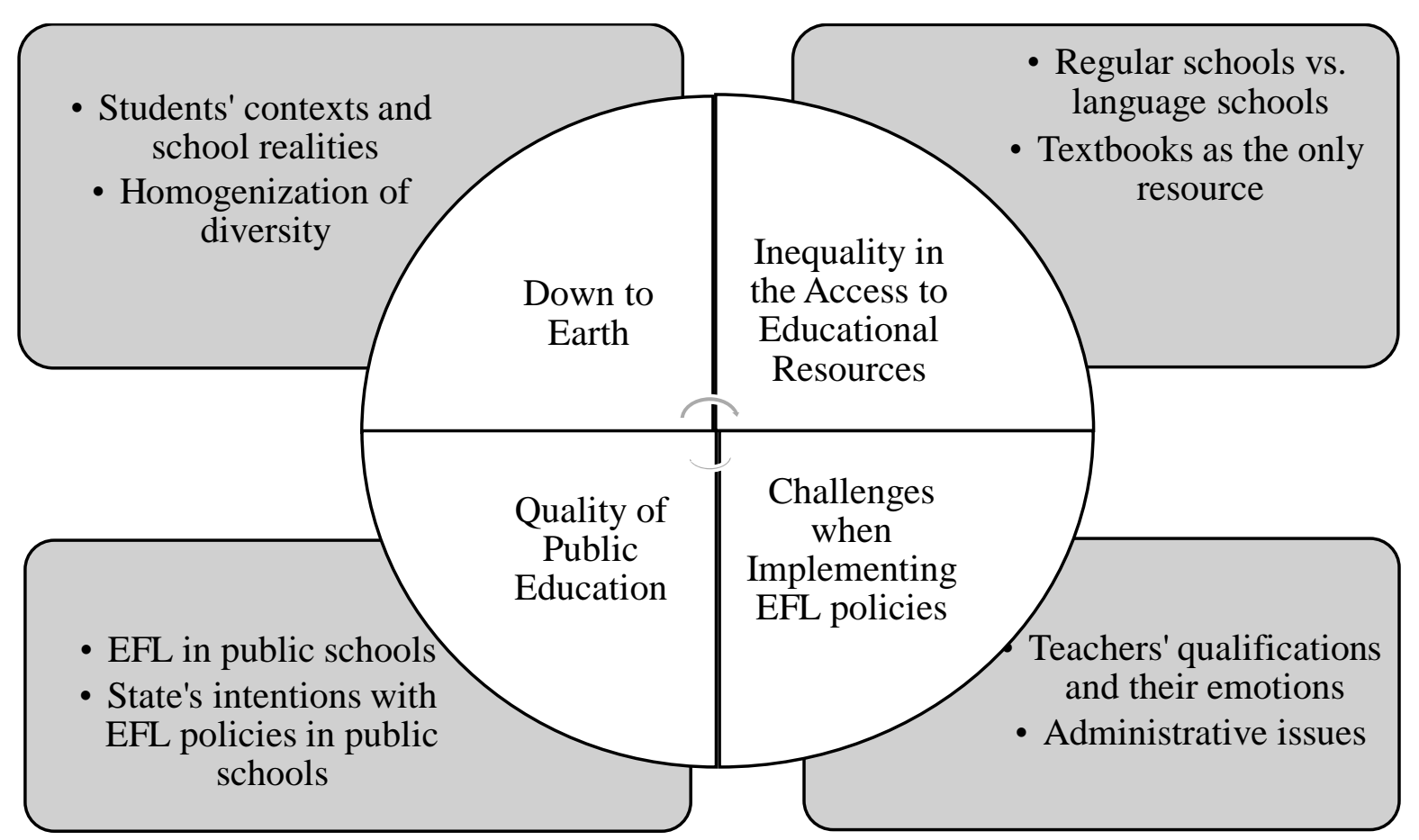

Figure 5. Main issues in articles

Down to Earth. When we talk about teaching and the challenges that this profession entails on a daily basis, we cannot leave the children's life outside of school aside. For example, Anyiendah (2017) worked in a Kenyan primary school, where absenteeism from school is high. Most of the families belong to deprived socioeconomic conditions, so parents struggle to make ends meet. Children have to do petty jobs to supplement family income, or they have to take care of their younger siblings while their parents work. Meanwhile in Venezuela, "priorities have to do with the political tension that the country is facing" (López d'Amico, Gregson, Medina, \& Esteves, 2018, p. 83). Even though Benson (2004) is from Sweden, her studies have been carried out in countries Mozambique and Bolivia, both of which have a wide diversity of cultures and languages. The main issue in her 
studies is the protection of cultural and linguistic values and identities given that indigenous communities have struggled with homogenization and monolingual processes. Furthermore, she has focused on the challenges of bilingual teachers who work in developing countries, and she advocates the idea that "thinking outside of a colonial frame is something we all could benefit from" (p. 217). Dutta and Bala (2012) from India have claimed that the child's life at school may not be related to his or her life outside of school.

In the same line of thought, Chan and Lo (2016) from Hong Kong, China showed another side of the coin when acknowledging the difficulty of handling a wide diversity of students in a single classroom due to migration and students' cognitive capabilities. In other parts of the world, the government has provided funds to support English classes. Such was the case in California with Proposition 227, which ruled that English instruction should be implemented for Limited English
Proficiency (LEP) students. Therefore, bilingual programs were eliminated in favor of English only classes. However, the implementation of this policy did not show a significant improvement in the students' standard test results under Proposition 227. The proposition was controversial in the sense that bilingual programs should promote school diversity due to immigration (García \& Curry-Rodríguez, 2000).

In the same way, Lo Bianco (2009) wrote about the richness of Australian language, culture, and history. Lo Bianco emphasized that "Every effort to redress persisting underperformance in language education is amply justified" (p. 64). If schooling is compulsory, "Bilingualism can foster more reflective and imaginative dispositions in citizens, and the principles of democratic discourse, participation, and opportunity" (p. 64).

Moreover, Anyiendah (2017), who works in Kenyan primary schools, stated that "Learners are not afforded the chance 
to learn from their own familiar home language with a curriculum and pedagogy that recognizes their cultural setting” (p. 3). For example, students may know white as snow in their home language. Benson (2004) considered that there is a mismatch between the language of the school and the language of the home (p. 205).

To sum up, the previous articles show the disconnect between real life and school life; students from diverse origins in the same classroom have to face homogenization processes when learning a language (in this case, English). Also, these articles show how scholars consider the need to take culture into account within the classroom in order to construct a more democratic and participatory society. After reviewing some of the uncertainties faced by families, students, teachers, and others every day in the article, I decided to focus on how resources for public education were being invested and distributed.

\section{Inequality in access to educational}

sources. Tuñón and Halperin (2010) from Argentina revealed through a longitudinal study that most underprivileged children (in primary schools) do not have specialized teachers for art, dance, physical education, technology, or languages. This inequality is related to resources access, which depends greatly on the student and family's socioeconomic status. Fragozo and Stedile (2012) from Brazil examined the differences between teaching English in public schools versus language institutes. They found that heavy workloads, large classes, lack of resources, and emphasis on reading and writing in public schools make English language learning less effective than at language centers (p. 82). In these studies, social disparity in access to educational sources in both public and private education was tackled.

De Mejia (2009) explained English Language Teaching (ELT hereafter) funds in Colombia are invested in the National Bilingual Program in the public sector, with 
special attention to the last two years of secondary school (tenth and eleventh grade). In relation to the use of resources, Usha Dutta and Neeru Bala (2012) acknowledged that most Indian schools spent money from outside contributions on colorful charts and posters, which were later kept under lock and key. Another key issue with access to educational resources comes from a study conducted by Correa and González (2016) from Colombia. They stated that all of the textbooks used as material in the classroom were written and published by foreign entities and displayed decontextualized discourses and content that did not match or address the local needs. Additionally, the effectiveness of the implemented material was measured through standardized tests (p. 20). Usha Dutta and Neeru Bala (2012) also looked at state textbooks for level 1 classes (Class I and II), for which they found that they focused less on listening and speaking skills rather than building familiarity with the language. Similarly, Panezai and Liaquat
(2017) stated that textbooks are the only available sources for English language teaching and learning in the Pakistani public education system. They understand the effectiveness of the English textbooks of Grades 1-5 through the eyes of the teachers who use them for teaching English practically in their environments. The researchers believe that teachers are the everyday implementers of the textbooks, and their perceptions, perspectives, and voices may contribute to the current debate regarding how quality education could be provided using the resources available.

Quality of public education. Tuñón and Halperin (2010) found that the quality of public education is related to the parents' educational level. The more educated a parent is, the lower his or her image of public education is. However, Dávila-Pérez (2013) from Colombia contrasted two public schools in Bogotá and found that belonging to a low socioeconomic class is not the only factor that impacts English learning imbalances or poor test results (p. 
231 - my translation). As Dávila-Pérez remarked, public school students are seen as unable to learn English, while the students themselves may feel that they do not need the language or have inherited low aspirations from their parents. In this case, teachers should encourage their students' autonomy to learn outside the classroom (p. 232- my translation). Nonetheless, parents are not completely oblivious to the learning process. Indeed, Tekin (2015) mentioned that parents in Oman are well aware of the benefits and challenges of early EFL education.

Valencia (2013), a Colombian scholar, carried out a discourse analysis that revealed that political discourses tend to dismantle public education by disdaining its capability to offer quality education. In this sense, Sayer (2015) explained that the expansion of English in Mexican public primary schools is a way to implement the neoliberal language policy. Along this same line of thought, Fallon and Rubik (2012) wrote an article about protecting the French language in Quebec, Canada - the official language is French- given the power rivalry between English and French. English as a second language has been introduced in primary schools because of economic reasons. Meanwhile, curriculums and strategies are geared toward developing a positive attitude toward learning English (p. 102).

By the same token, MaldonadoValentin (2016) stated that in Puerto Rico the role of English depends on the political party that is in power and its relationship with the USA. Nowadays, English has become another school subject in public education. Finally, Almeida (2016) claimed that English language teaching, which is taught from first grade in Brazilian public schools, seem to serve the interests of private institutions, language courses, and publishing houses. Unfortunately, students who come from poor, working families and attend public school tend to do unsatisfactory on standardized exams. Consequently, private language institutes 
benefit from these adverse circumstances (p. 16).

The articles mentioned above reflect some of the situations regarding EFL in public schools and the government's intentions with EFL policies. The following section acknowledges a few of the challenged faced in EFL classrooms.

\section{Challenges when implementing}

EFL policies in classes. De Mejia and Fonseca (2009) stated that there are neither bilingual nor multilingual guidelines for foreign languages in Colombia. However, they also recognized that the Common European Framework of References standards constitute a common approach to talk about the achievements and aims of English teaching. Furthermore, CadavidMúnera, McNulty, and Quinchía-Ortiz (2004) found that English taught in Colombian public primary schools is restricted to basic vocabulary, grammar, and pronunciation due to teachers' low proficiency level. Additionally, teachers use translation as a way to make themes understood, so students are exposed more to Spanish than to English (p. 45). Consequently, there is a need to inquire about our real needs in relation to English in order to create suitable policies for our settings.

In addition, Martínez (2009) established that Salvadorian students do not learn English in public schools because of the following reasons: teachers are unqualified in terms of language proficiency and methodologies; students lack interest in to learning English; teachers use the translation method; and the official program does not have clear objectives for learning the language. Related to the above, Wen-Chuan (2015) from Taiwan found that the English language teaching methodologies at public schools were poles apart. On the one hand, teachers used games and the communicative approach, while others utilized cognitive processes. Because of this, students feel lost when they move from primary to secondary school. 
In India, Anjali Mody (2015)

pointed out that most English teachers are limited to reading from a textbook. Teachers in primary school have 10 to 20 years of teaching experience each, and they all have to teach English as a subject to their students. However, most of these teachers have difficulty speaking grammatically correct sentences in English. Accordingly, Usha Dutta and Neeru Bala (2012), also from India, stated that children did not get an opportunity to listen to the language or speak in English. They were not able to narrate experiences, exchange ideas, and carry out brief conversations in English. In these case, teacher training programs are essential in order to encourage teachers to avoid "The Textbook Trap" and grammarcentered classes. Moreover, school libraries were found to be inadequately equipped and sparsely furnished, even nonexistent.

On the other hand, Gholami, Sarkhosh, and Abdi (2016) carried out a study with Iranian public secondary EFL teachers, and they found that teachers who worked previously with private language institutions "subscribe more closely to the tenets of communicative language teaching and thus can act as powerful agents of sustainable language teaching in Iranian public schools" (p. 16).

Görsev İnceçay (2012) from Turkey stated that challenges when implementing English in primary schools are related to "the crowded classroom and lack of necessary equipment and support from policy makers, administration and colleagues" (p. 53). Additionally, Abrar (2016) from Indonesia considered that the lack of learners' motivation, insufficient lesson time, low resources and materials, and overcrowded English classes (p. 100) were the main deficiencies that needed to be overcome. Finally, Intriago (2017) from

Ecuador claimed that ELT implementation in public primary schools in Ecuador is unfeasible due to the shortage of trained teachers, the weak curriculum, and the scarcity of economic resources. Therefore, Hayes (2017), who has carried out studies 
in Asia, suggested that ELT at an early age should be implemented only after carefully analyzing educational issues.

After having reviewed some of the challenges recognized by academics inside the classroom, it is time to look at how teachers feel about these issues. At a Colombian public primary school, Quintero-Polo and Guerrero-Nieto (2013) studied teachers' identities and positions. They argued that teachers' identities oscillate depending on the position they have. If they are talking about teaching, they appear professional because they know about the teaching/learning processes. Nonetheless, when they describe their role regarding policies designed by the State, they feel powerless, with little to say (p. 202). Similar to the previous authors, Machida and Walsh (2015) carried out a qualitative study in Japan, and they found that teachers were anxious when speaking English in classes. They also perceived assistant language teachers (native English speakers) as unqualified to teach.
According to Maturana (2011), Colombian public primary school teachers who participated in her study perceived English language teaching as something imposed and incidental. Additionally, the school preferred specialized English language teachers in public primary schools. Equally, the most striking factors that hinder ELT implementation to children in Puebla-Mexico are related to the teachers" "low payment, the lack of proper conditions in terms of the facilities, resources and equipment, and the absence of prior specialization in the field" (Mendoza-Vallares \& Puón-Castro, 2013, p. 4). Furthermore, teachers expressed that they struggled to manage large groups: teaching children of different ages at the same time in big groups. What is more, English teachers have to confront homeroom teachers' beliefs. As mentioned by the authors, homeroom teachers thought that EFL distracted students from “important" classes (i.e. Math, Science, and Spanish), and it was a waste of time. 
Additionally, the homeroom teachers believed that the students only played games in their English classes.

As if this were not enough, homeroom teachers who studied in Normal ${ }^{1}$ institutions discriminated teachers who had completed an undergraduate teaching degree. Without a doubt, there exists a rivalry between these two groups, with homeroom teachers believing they were the best teachers at the school. MendozaVallares and Puón-Castro (2013) also found that some of the school principals and parents rejected English classes because they felt that they students did not need to learn English. After all, they were not going to travel abroad.

On the other hand, RamírezRomero and Sayer (2016) believe that in spite of Mexican teachers' working conditions, most English language teachers struggle to give their best to the most needed (students who had never received

\footnotetext{
${ }^{1}$ Normal institutions according to the Law 115 of
} 1994 , article 112, are public high schools that offer
English lessons before) (p. 18). In a way, they tried to reduce the gap between privileged and deprived children in terms of English language learning access.

All in all, the section Down to Earth explored students' contexts and school realities with the tensions between them. Additionally, ELT lessons seem to promote homogenization of the great diversity possessed by students. Inequality in the Access to Educational Resources presented studies that showed the conflict between regular schools and language centers. For the most part, school textbooks are the only resource used to teach English in a public setting. Then, the Quality of Education was addressed in regard to TEFL in public school and the State's intentions in promoting EFL policies. Finally, Challenges when Implementing EFL Policies brought together some analyses on teachers' qualifications and administrative issues that constitute shortcomings that can work at the preschool and primary level. 
stakeholders in public schools need to overcome.

In the following section, I want to acknowledge the researchers who have taken the initiative to propose improvements in English language teaching in public settings. To do so, I organized the proposals into three main themes, which are displayed in Figure 6. They are called Voices for policymaking, Teachers' programs, and Hopeful perspectives.

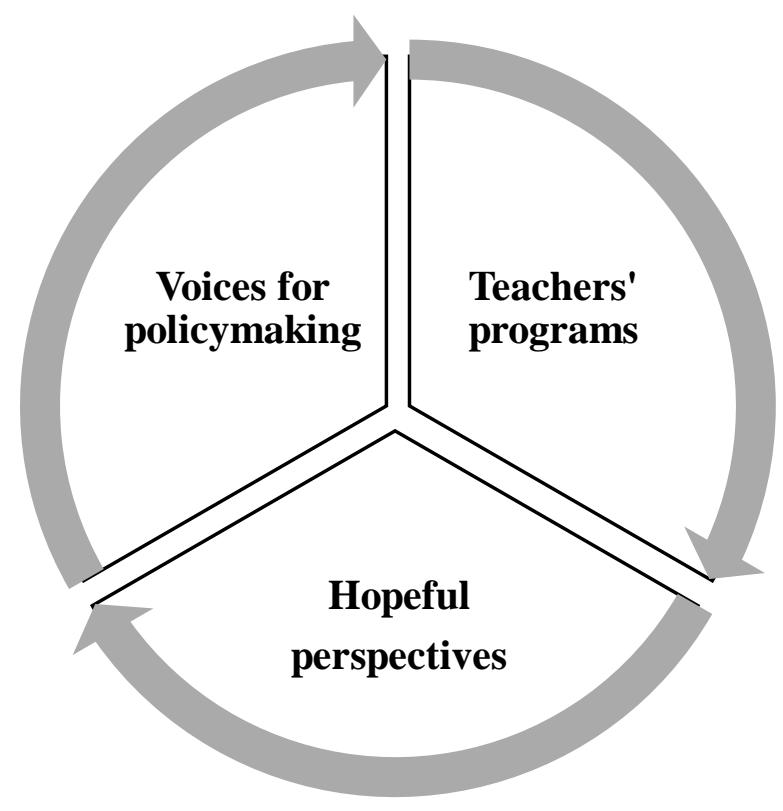

Figure 6. Scholars' proposals

\section{Voices for Policymaking}

Basurto and Weathers (2016) from

Mexico acknowledged that teachers are the ones who know the reality in the classroom. Thus, stakeholders should consider teachers' understanding in order to plan and establish educational changes. For example, in Japan, $\mathrm{Ng}$ (2016) found that stakeholders did not sufficiently consider challenges faced by schools and teachers when implementing primary school English programs. Apparently, policies were made in a rush (p. 92). A similar situation is faced in Chile, where Barahona (2016) found a mismatch between policy aspirations and implementations in real contexts. Moreover, in Argentina, Porto (2016) contemplated the limitations that exist 
regarding the implementation of language policies. However, a common shared perspective on English language teaching includes promoting intercultural citizenship through task-based, project-based, and CLIL (Content Language Integrated Learning) methodologies (p. 21).

What is more, Usma (2009) criticized that fact that policies exclude local knowledge and classify students and teachers based on test scores and/or marketed institutions and certifications (p. 137). On the other hand, Alrabai (2016) from Saudi Arabia supported the idea of English for economic development. From my point of view, he provided advice for the problems he observed in his witness, but they are out of his reach because the legislators are in charge of the State's funding.

Another weakness in decontextualizing English language educational policies are that they are far from the priorities of public schools, especially rural communities (Peláez \&
Usma 2017, p. 129). In these policies "the ideal of English is separated from people's real existence" (p. 130). For this reason, language guidelines should consider all levels -local, regional, national- and the individuals (teachers), who implement the policies (p. 132). Similarly, for Correa and González (2016), language policymaking should pay attention to the expertise of those who carry out the policies: teachers and teacher trainers (p. 20).

On the other hand, Zein (2017) from Indonesia strongly believes that English should be introduced as a compulsory subject in primary school because:

Community policy needs to ensure the establishment of a consortium that would become an umbrella organization to connect stakeholders involved in primary EFL education with the government. Furthermore, resourcing policy needs to ensure that funding and resources are geared towards the improvement 
of more pressing and immediate needs in curriculum policy, methodology and material policy, personnel policy and evaluation policy. (p. 144)

Correspondingly, Straková (2015) from Slovakia considered that introducing English as a foreign language in the early years depends on each school's organization. Teacher qualification is an important factor to keep in mind, as well as students' exposure to more hours of English (p. 2442). Nevertheless, several factors need to be considered before implementing English early on. Medina, Ruiz García, López D’Amico, Gregson, Esteves, and Romero Sosa (2018) found that in order to introduce English beginning at the primary school level in Venezuela, stakeholders should agree on the following criteria: teaching purpose, number of hours devoted to English, content to context adaptation, knowledge sharing with other countries, and language institution alliances (e.g. British Council) (p. 96).
From a different perspective, Galindo and Moreno's (2008) proposal consisted of taking into account other languages, such as Mandarin Chinese, French, Portuguese, Italian, and Dutch, as international languages (p. 179).

All in all, Cárdenas (2006) stressed the need to consider regional diversity, local expertise, and flexible approaches to teaching and assessing. Meanwhile, Fandiño-Parra (2014) suggested adopting a critical socio-cultural model to change the school's reality according to needs (p. 216). In other words, researchers agree that teachers and stakeholders should be involved in designing more realistic policies based on the complexities, needs, and talents of the context.

Subsequently, scholars recommend that teachers' programs should also consider their expertise, understanding, and studies. They also encourage universities to revise their programs in light of their contexts and realities. 
Teachers' programs. Mede (2017)

from Turkey recommended that programs for future language teachers should focus on skills development to be implemented with young learners at school. Almeida (2016) from Brazil encouraged universities to analyze their ELT programs for preservice and in-service teachers to avoid commercial interests over educational ones. Also, State needs to empower primary teachers' autonomy so they can make decisions in their own surroundings (p. 16).

In Colombia, Cárdenas, González, and Álvarez (2010) suggested that English teacher programs should consider development over training; adopt a sociocultural perspective; be context sensitive and autonomous; use post method theory; research and reflect in the teacher's context; and perceive teachers as knowledge constructors (p. 64). Maturana (2011) also proposed that teachers' development programs should improve both communicative and pedagogical competences (p. 86).
Cronquist and Fiszbein (2017) provided a British perspective suggested that English language teachers should organize communities to learn from their neighbors' experiences, create immersion programs without traveling abroad, improve language teachers' competences, and promote distance learning (p. 72).

In Costa Rica, Solano (2012) proposed that English teachers could use critical historical thinking and transdisciplinary and comparative perspectives of social justice in their lessons to create their own language critical pedagogy, which could transform their practices (p. 52).

In relation to the evaluation processes, Rico-Troncoso (2014) remarked that "It is necessary to consider the evaluation within the training programs of in-service teachers in order to articulate it and integrate it into their pedagogical practices and thus close the gap between 
teaching and evaluation ${ }^{2 "}$ (p. 4). He also suggested that "the programs respond to the need of language teachers in terms of providing spaces in which they reflect and share experiences in relation to strategies, techniques, and methodologies inherent to the design of pedagogical materials" (p. 5). Capperucci (2017) from Italy also encouraged paying attention to curriculum design, subject knowledge, and the ability to use teaching and learning strategies (p. 217) in teachers' programs. From the same country, Bondi and Poppi (2007) devised a certificate for English language teachers in primary school, which takes into account connections between three main components: language, pedagogy, and language awareness (p. 154).

Finally, Gkaintartzi and Tsokalidou (2011) from Greece stated that teacher programs should promote diversity awareness, interculturality, and understanding of the role of ideologies when teaching to avoid the perpetuation of inequalities. In short, most scholars agree on the idea of revising teacher programs so that they meet students' real needs and future teachers' life projects. The following section presents suggestions from scholars directed toward the Colombian context.

\section{Hopeful Perspectives}

Fandiño-Parra, Bermúdez-Jiménez, and Lugo-Vásquez (2012) remarked that bilingual education for Colombian elementary and high-school students are two main challenges that have emerged since 2004 when the National Bilingual Program (NBP) was passed by the Ministry of Education (MEN). Because of this, the MEN should analyze how the NBP can contribute to helping students become aware of linguistic and cultural diversity around the world. Furthermore, students should learn who to respect each other and protect cultural and linguistic difference (p. 377). If this were the case, the focus of the NBP should be on inter and multicultural competences that allow educational

\footnotetext{
${ }^{2}$ Translated by the author.
} 
communities to organize local and regional projects (pp. 377-378). Additionally, De Mejia (2006) encouraged policy makers to value the linguistic and cultural diversity of our country. Indeed, Bonilla and TejadaSánchez (2016) argued that Colombian teachers have to overcome teaching English mechanically. Teachers should promote critical thinking from a critical literacy perspective that allows students to read and understand from different points of view. They also claim that our main goal as a nation is to eradicate poverty, reduce inequalities, and live in peace (pp. 197198).

As a way to conclude, the next section aims at posing some questions in relation to what scholars know, or have not yet noticed, about teachers' practices when teaching English in public institutions.

Some Gaps in Relation to Teachers' Practices

Li (2010) from China explained that:
Content analysis was employed to analyze the data to show that EFL teachers were not following the instructions in the national English curriculum to guide their classroom teaching, but were rather critical to the objectives and requirements described in the curriculum. The reason for this was revealed to be the gap between the curriculum policy and practical teaching situations. The results suggested that involving classroom teachers in policy making may help the national language curriculum be more applicable and implementable. This may shed light on the question of whether teachers are just implementers or whether they help to shape and develop the policy. (p. 440)

Rico-Troncoso (2014) analyzed English language teachers' innovative projects and found that most of the experiences are carried out in urban areas, 
mainly in secondary schools in Bogotá. "It is unknown what English teachers assess and how they do $\mathrm{it}^{3 "}$ (p. 4).

Finally, Usma (2009) claimed that there is a lack of studies regarding "how school communities interpret, enact, resist, and transform policy discourses and practices and use them as opportunities for personal and community development" (p. 138). Accordingly, the panorama regarding EFL policies has been described and studied for almost two decades, but little has been said about how public primary school teachers appropriate, reject, modify, and/or overlook these policies in their classrooms.

\section{About the Author}

Mireya Esther Castañeda holds a B.Ed. in Philology and Languages-English, a M.A. in Applied Linguistics in TEFL, and a specialization in educational management. She is a Ph.D. student in the "Doctorado Interinstitucional en Educación" program at Universidad Distrital Francisco José de Caldas. She has worked with students from kindergarten to university, and she has been an item writer for State exams. Currently, she works for the Secretaría de Educación del Distrito, SED, as a coordinator.

\section{References}

Abrar, Mukhlash. (2016, October). Teaching

English problems: An analysis of EFL primary school teachers in Kuala Tungkal. [Paper presentation] The 16th Indonesian Scholars International Convention, Birmingham, UK https://www.researchgate.net/publi cation/314280291_TEACHING_E NGLISH_PROBLEMS_AN_ANA LYSIS_OF_EFL_PRIMARY_SCH

\footnotetext{
${ }^{3}$ Translated by the author.
} 
OOL_TEACHERS_IN_KUALA_ TUNGKAL

Alrabai, F. (2016). Factors underlying low achievement of Saudi EFL learners. international journal of English linguistics. International Journal of English Linguistic, 6(3), 1-17. doi: 10.5539/ijel.v6n3p21.

Almeida, R. (2016). ELT in Brazilian public schools: History, challenges, new experiences and perspectives. Education Policy Analysis Archives, 24(81).

http://dx.doi.org/10.14507/epaa.24. 2473.

Anyiendah, M. S. (2017). Challenges faced by teachers when teaching English in public primary schools in Kenya. Front. Educ. doi: 10.3389/feduc.2017.00013 https://doi.org/10.3389/feduc.2017.0 0013

Barahona, M. (2016). Challenges and accomplishments of ELT at primary level in Chile: Towards the aspiration of becoming a bilingual country. Education Policy Analysis Archives, 24(82). http://dx.doi.org/10.14507/epaa.24. 2448.

Basurto Santos, N. M., \& Gregory Weathers, J. R. (2016). EFL in public schools in Mexico: Dancing around the ring? $\mathrm{HOW}, 23(1), 68-$ 84.

http://dx.doi.org/10.19183/how.23.1. 297

Benson, C. (2004). Do we expect too much of bilingual teachers? Bilingual teaching in developing countries, International Journal of Bilingual Education and Bilingualism, 7(2), 204-221, doi: 10.1080/13670050408667809

Bondi M., \& Poppi F. (2007). Devising a language certificate for primary school teachers of English. PROFILE: Issues in Teachers' Professional Development, 8, 145164.

Bonilla Carvajal, C. A., \& Tejada-Sánchez, I. (2016). Unanswered questions in Colombia's language education policy. PROFILE: Issues in Teachers' Professional Development, 18(1), 185-201. http://dx.doi.org/10.15446/profile.v 18n1.51996. 
Cadavid-Múnera, I., McNulty, M., \&

Quinchía-Ortiz, D. (2004).

Elementary English language

instruction: Colombian teachers'

classroom practices. Profile: Issues

in Teachers' Professional

Development, 5(1), 37-55.

Capperucci, D. (2017) English language teaching and learning in primary school. Theoretical and methodological perspectives. Firenze University Press, doi: 1013128/Studi_Formaz-22181

Cárdenas, M. L. (2006, January). Bilingual Colombia. Are we ready for it? What is needed? [Paper presentation] 19th Annual English Australia Education Conference, Perth, Australia.

Cárdenas, ML., González, A. \& Álvarez, J. (2010) El desarrollo profesional de los docentes de inglés en ejercicio: algunas consideraciones conceptuales para Colombia. Folios Segunda época, 31(1), 49-68. doi: https://doi.org/10.17227/012348 70.31 folios 49.67

Chan, C., \& Lo, M. (2016). Exploring inclusive pedagogical practices in Hong

Kong primary EFL classrooms. Faculty of Education, University of Hong Kong, Hong Kong. International Journal of Inclusive Education, 21(7), 714-729.

Correa, D., \& González, A. (2016) English in public primary schools in Colombia: Achievements and challenges brought about by national language education policies. Education Policy Analysis Archives 24(83). http://dx.doi.org/10.14507/epaa.24. 2459

Council of Europe. (2001). Common European Framework of Reference for Language: Cambridge. Cambridge University Press

Cronquist, K., \& Fiszbein, A. (2017) El aprendizaje del inglés en América Latina. Pearson. Retrieved from www.pearson.com.ar/White_Paper. pdf

Dávila-Pérez, D. (2013) Capital lingüístico y desigualdad de oportunidades educativas: exploración en dos colegios de Bogotá Colombia. Revista Colombiana de Sociología. 36(2), 215-234. 
De Mejia, M.A. (2006). Bilingual education in Colombia: Towards a recognition of languages, cultures and identities. Colombian Applied Linguistics, 8, 152-168.

De Mejía, M. A., \& Fonseca, L. (2009).

Orientaciones para políticas bilingües y multilingües en lenguas extranjeras en Colombia. Retrieved from https://docplayer.es/10212061Orientaciones-para-politicasbilingues-y-multilingues-enlenguas-extranjeras-encolombia.html

De Mejia, MA. (2009). Teaching English to young learners in Colombia: Policy, practice and challenges. $M E X$ TESOL, 33(1), 103-114.

Dutta, U., \& Bala, N. (2012). Teaching of English at primary level in government schools. National Council of Educational Research \& Training. http://www.ncert.nic.in/department s/nie/del/publication/pdf/English_P rimary_level.pdf

Fallon, G., \& Rublik, N. (2012) Secondlanguage education policy in Quebec: A critical analysis of the policy of English as a compulsory subject at the early primary level in Quebec. TESL Canada Journal, 28(2), 90-104.

Fandiño-Parra, Y., Bermúdez-Jiménez, J., Lugo-Vásquez, V. (2012). Retos del programa nacional de bilingüismo: Colombia Bilingüe. Educación y Educadores, 15(3), 363-381.

Fandiño-Parra Y. (2014) Bogotá bilingüe: Tensión entre política, currículo y realidad escolar. Educación y Educadores, 17(2), 215-236.

Fragozo, C. \& Stedile, M. D. (2012). English teaching and learning in Brazilian regular schools and language schools: A study on teachers' beliefs. Journal of Education and Learning, 1(2), 8294.

García, E. E., \& Curry-Rodríguez, J. E. (2000). The education of limited English proficient students in California schools: An assessment of the influence of Proposition 227 in selected districts and schools. Bilingual Research Journal, 24(1), 15-35. 
doi: 10.1080/15235882.2000.10162 749

Gholami, J., Sarkhosh, M., \& Abdi, H. (2016). An exploration of teaching practices of private, public, and public-private EFL teachers in Iran, Journal of Teacher Education for Sustainability, 18(1), 16-33. doi: https://doi.org/10.1515/jtes-20160002

Gkaintartzi, A., \& Tsokalidou, R. (2011). "She is a very good child but she does not speak: The invisibility of children's bilingualism and teacher ideology. Journal of Pragmatics, 43.

doi:10.1016/j.pragma.2010.09.014

González, A. (2009). Professional development of EFL teachers in Colombia: Between colonial and local practices. Íkala, 12 (1), 309332.

Görsev İnceçay (2012). Turkey’s foreign language policy at primary level: Challenges in practice. Language Education and Applied Linguistics ELT Research Journal 2012, 1(1), 53-62.
Guerrero, H. (2018) ELT Local Research Agendas I. Part II, problematizing ELT education in Colombia: Contradictions and possibilities. Doctorado interinstitucional en educación. Universidad Distrital Francisco José de Caldas. Bogotá.

Hayes, D. (2017). Fallacies affecting policy and practice in the teaching of English as a foreign language in state primary schools in Asia. Pacific Journal of Education, 37(2), 179-192.

Intriago, E. (2017) English as foreign language in Ecuadorian primary schools before its official introduction into the national curriculum. What have we learned from it? Turkish Online Journal of Educational Technology, 291-297.

Li, M. (2010). EFL teachers and English language education in the PRC: Are they the policy makers? The AsiaPacific Education Researcher, 19(3), 439-451.

Lo Bianco, J. (2009). Second languages and Australian schooling. Camberwell, Victoria: Acer Press. 
López d'Amico, R., Gregson, M., Medina, S. M., \& Esteves, F. (2018). English language teaching within the state education system in Venezuela: Goals, achievements and challenges. Retrieved from https://www.britishcouncil.org.mx/ sites/default/files/rpd_publication.p df

Machida, T., \& Walsh, D.

J. (2015). Implementing EFL policy reform in elementary schools in Japan: A case study. Current Issues in Language Planning, 16(3), 221237.

doi: 10.1080/14664208.2015.97072 8

Maldonado-Valentin, M. (2016). An exploration of the effects of language policy in education in a contemporary Puerto Rican society. Education Policy Analysis Archives, 24(85).

http://dx.doi.org/10.14507/epaa.24. 2453.

Martinez, N. (2009). Diá-logos. Revista de Educación, 4, 39-55. Retrieved from

http://www.redicces.org.sv/jspui/bit stream/10972/2032/1/3.\%20Por\%2 0que $\% 2010$ \% $\% 20$ estudiantes\%20de \%20las\%20escuelas\%20publicas\% 20no\%20aprenden\%20ingles.pdf

Maturana, L. (2011). La enseñanza del inglés en tiempos del plan nacional de bilingüismo en algunas instituciones públicas: Factores lingüísticos y pedagógicos. Colombian Applied Linguistics Journal, 13(2), 74-87.

Mede, E. (2017). Teachers'self-reported beliefs on developmentally appropriate and inappropriate practices in grade $\mathrm{K}$ 4 EFL classrooms. International Journal of Primary, Elementary and Early Years Education, 45(4), 462476.

Medina, S. M., Ruíz García, J. K., López d'Amico, R., Gregson, M., Esteves, F., \& Romero Sosa, L (2018). The Venezuelan national advanced training programme for the improvement of quality in teaching in primary Schools. Retrieved from https://www.britishcouncil.org.mx/site s/default/files/rpd_publication.pdf

Mendoza-Vallares, J., \& Puón-Castro Y. (2013). The challenge of teaching English in public schools: Beyond 
academic factors. MEXTESOL Journal, 37(3).

Ministerio de Educación Nacional. (2006). Guía No. 22 Estándares Básicos de Competencias en Lenguas Extranjeras: Inglés. Retrieved from https://www.mineducacion.gov.co/ 1759/w3-article115174.html?_noredirect=1

Ministerio de Educación Nacional. (n.d.). Ley

115 decreto 1860. Retrieved from https://www.mineducacion.gov.co/ 1759/w3-propertyvalue-51457.html Ministerio de Educación. (2015). Ley 1753 del Plan Nacional de Desarrollo 2014-2018 "Todos por un nиеvo país". $\quad$ Retrieved from https://www.mineducacion.gov.co/ 1621/articles355154_foto_portada.pdf

Ministerio de Educación. (2015a). Colombia, la mejor educada en el 2025: Líneas estratégicas de la política educativa del Ministerio de Educación Nacional. Retrieved from

https://www.mineducacion.gov.co/ 1621/articles355154_foto_portada.pdf
Mody, J. (2015). India's obsession with English is depriving many children of a real education. QUARTZ India. Retrieved from https://qz.com/india/494396/indiasobsession-for-english-is-deprivingmany-children-of-a-real-education/

Ng, Patrick. (2016). Primary school English reform in Japan policies progress and challenges, Current Issues in Language Planning, 1-11.

Panezai, S. G. \& Liaquat, A. (2017).

Pakistani government primary school teachers and the English textbooks of Grades 1-5: A mixed methods teachers'-led evaluation. Journal Cogent Education, 4(1).

Peláez, O., \& Usma, J. (2017). The crucial role of educational stakeholders in the appropriation of foreign language education policies: A case study. PROFILE: Issues in Teachers' Professional Development, 19 (2), 121-134. doi:https://doi.org/10.15446/profile .v19n2.57215

Porto, M. (2016). English language education in primary schooling in Argentina. Education policy analysis archives, 24 (80). 
Quintero-Polo, A., \& Guerrero-Nieto, C. H. (2013). "Of Being and not being": Colombian public elementary school teachers' oscillating identities, HOW, 20(1), 190-205.

Ramírez-Romero, J. L., \& Sayer, P. (2016). The teaching of English in public primary schools in Mexico: More heat than light? Education Policy Analysis Archives, 24(84). http://dx.doi.org/10.14507/epaa.24. 2502.

Rico-Troncoso, C. (2014). Rasgos característicos de la enseñanza de inglés como lengua extranjera en Colombia. Análisis de las propuestas pedagógicas presentadas al Premio Compartir al Maestro. Palabra Maestra, 37, 3-5.

Sayer, P. (2015) More \& earlier:

Neoliberalism and primary English education in Mexican public schools. L2 Journal, 7(3). http://dx.doi.org/10.5070/L273236 02

Solano, A. (2012). Teaching and learning English in Costa Rica: A critical approach. Letras, 52.
Straková, Z. (2015). Challenges of teaching English at primary level. Procedia Social and Behavioral Sciences, 174 , doi:

10.1016j.sbspro.2015.01.914

Tekin, A. K. (2015). Early EFL education is on the rise in Oman: A qualitative inquiry of parental beliefs about early EFL learning. English Language Teaching, 8(2), 35-43.

Tuñón, I., \& Halperin, V. (2010).

Desigualdad social y percepción de la calidad en la oferta educativa en la Argentina urbana. Revista electrónica de investigación educativa, 12(2), 1-23. http://www.scielo.org.mx/scielo.ph p?script=sci_arttext\&pid=S160740412010000200005\&lng=es\&tlng $=\mathrm{pt}$

Un Mapamundi. (n.d.). [Mapamundi político] [Image] Un Mapamundi. https://www.google.com/search?tb $\mathrm{m}=\mathrm{isch} \& \mathrm{q}=$ mapamundi $\& \operatorname{chips}=\mathrm{q}$ : mapamundi,g_1:politico,g_1:grand $\mathrm{e} \& \mathrm{sa}=\mathrm{X} \& \mathrm{ved}=0 \mathrm{ahUKEwjexquTkp}$ vhAhUStlkKHd70AywQ4IYIKigD $\&$ biw $=1745 \&$ bih $=881 \&$ dpr $=1.1 \# \mathrm{i}$ mgrc $=0 j z \_T z t i Q L d X p M$ : 
Usma, J. (2009) Education and language policy in Colombia: Exploring processes of inclusion, exclusion. PROFILE: Issues in Teachers' Professional Development 11, 123 141.

Valencia, M. (2013). Language policy and the manufacturing of consent for foreign intervention in Colombia. PROFILE: Issues in Teachers' Professional Development, 15(1), 27-43.

Wen-Chuan Lin (2015). The early bird catches the worm? Rethinking the primary-junior high school transition in EFL learning. The Asian Journal of Applied Linguistics, 2(1), 17-27.

Zein, S. (2017). Language-in-education policy on primary EFL: The case of Indonesia. International Journal of Pedagogies \& Learning, 12(2), 133146. 